\title{
La teoría literaria como forma de intervención en lo público. Reflexiones teóricas, ejemplos argentinos y un caso cubano: la revista Diáspora(s)
}

\author{
IGNACIO IRIARTE Universidad Nacional de Mar del Plata - CONICET, Argentina / iriarteignacio@yahoo.com.ar
}

\section{Resumen}

Este trabajo tiene como propósito abordar algunos usos de la teoría literaria en América Latina. En la primera parte, elaboro una serie de reflexiones sobre la teoría, la ética y la relación que la teoría literaria mantiene con la sociedad. A partir de estas reflexiones, formulo la hipótesis de que la teoría es una forma de intervenir en lo social. En la segunda parte propongo un repaso breve por algunos usos de la sociología de la cultura que se hicieron en Argentina en los años 80 y 90 . En la cuarta parte pongo a prueba la hipótesis por medio de una descripción de la revista cubana Diáspora(s), publicada entre 1997 y 2002.

Palabras clave: teoría / política / Argentina / Cuba / Diáspora(s)

\begin{abstract}
Literary theory as a form of public intervention. Theoretical issues, argentinian examples and a case: the Cuban magazine Diáspora(s)

Abstract

This paper aims to analyze some uses of literary theory in Latin America. In the first part, I reflect on the theory, ethics and relationship that literary theory maintains with society. From this, I formulate the hypothesis that the theory is a way of intervening in the social. In the second part, I brie fly review some uses of the sociology of culture that we remade in Argentina in the 1980s and 1990s. In the fourth part, I propose to test the hypothesis through an analysis of the Cuban magazine Diáspora(s), published between 1997 and 2002.
\end{abstract}

\section{Key words: theory / politics / Argentina / Cuba / Diáspora(s)}

Recibido: 13/8/2018. Aceptado: 9/10/2018

Para citar este artículo: Iriarte, Ignacio (2018). La teoría literaria como forma de intervención en lo público. Reflexiones teóricas, ejemplos argentinos y un caso cubano: la revista Diáspora(s). El taco en la brea, 8 (junio-noviembre), 110-131. Santa Fe, Argentina: UNL. DOI: 10.14409/tb.v1i8.7760 
Como cuenta Paul de Man, la primera versión del famoso «La resistencia a la teoría» fue escrito a pedido de la Modern Language Association para formar parte de un volumen colectivo titulado Introduction to Scholar ship in Modern Languages and Literatures en el que él presentaría las principales tendencias, publicaciones, zonas problemática y agendas de investigación dela teoría literaria. No tardó, sin embargo, en darse cuenta de que se trataba de un proyecto imposible de cumplir, porque, según argumenta al principio de su ensayo, «el principal interés teórico de la teoría literaria consiste en la imposibilidad de su definición» (11). La teoría podría definirse si fuera un diccionario de conceptos técnicos, como prosa, verso, rima, narrador, personaje, o bien si constituyera un árbol de conceptos deductivos, a la manera de las poéticas que se elaboraron al principio de la Ilustración, pero la verdad es que la teoría no es nada de eso. Para de Man, la teoría aparece cuando los estudios literarios abandonan las determinaciones históricas o culturalistas y adoptan la lingüística estructuralista. A partir de ese momento, «el objeto de debate ya no es el significado o el valor sino las modalidades de producción y de recepción del significado y del valor» (17). En otras palabras, la teoría deja de lado la idea de que el texto es una serie de signos que transmiten un significado, y comienza a comprender los textos como redes de significantes que producen significados siempre provisorios y perecederos. El nacimiento de la teoría se produce cuando se pone en cuestión la estabilidad del objeto al que ésta se referiría. Por ese motivo, la teoría no tiene definición. Esto genera una resistencia que se vuelve intrínseca a ella:

La resistencia a la teoría —escribe de Man— es una resistencia a la dimensión retórica o tropológica del lenguaje, una dimensión que quizás se halle más explícitamente en primer plano en la literatura (concebida de un modo amplio) que en otras manifestaciones verbales o — por ser menos vago — que puede ser revelada en cualquier acontecimiento verbal cuando es leído textualmente. (32)

Aunque «La resistencia a la teoría» se publicó hace más de treinta años, esta tesis de que la teoría literaria comprende el texto como un dispositivo de producción de sentido y no como la encarnación de significados y valores preestablecidos sigue siendo el punto de partida para cualquier reflexión seria sobre el tema. En este trabajo quisiera partir, entonces, de esta propuesta. En las páginas que siguen voy a desplegar el tema por medio de algunas reflexiones teóricas, luego voy a describir, de manera fugaz, algunos usos de la sociología de la cultura en Argentina, para detenerme, finalmente, en la revista cubana Diáspora(s), tomándola como el ejemplo central de este trabajo.

\section{Umbrales de la teoría}

En el ensayo de Paul de Man, la lingüística funciona como un umbral teórico. Hablo de «umbral», en primer lugar, porque el estructuralismo constituye una especie de frontera que le da una dimensión teórica a los estudios literarios. En este sentido, la lingüística es un umbral, como el umbral que atravesamos cuando entramos o salimos de una habitación, un edificio o una casa. Pero lo es también porque la palabra umbral tiene entre sus connotaciones la idea de que, en ese traspaso, exista una mutación en cuanto a lo que sabemos y podemos pensar, lo que explica que la invención de la teoría no tenga sólo un impacto hacia adelante, porque lo cierto es que reconfigura también la manera en la que comprendemos el pasado. Esta es una cuestión que no se puede soslayar, porque la apuesta teórica está articulada con todo un giro deconstructivo que rompe 
con las concepciones esencialistas del ser humano e incluso con las formas de organización de la sociedad por medio de conceptos a-históricos como nación, pueblo o raza. Por último, podemos decir que la teoría aparece cuando uno se sitúa en un cierto umbral, como si retrocediéramos respecto de los usos naturalizados del lenguaje, ese bullicio cotidiano de la comunicación, para mirar desde esa forma de umbral que es la línea que separa el significante del significado. Paul de Man desarrolla el tema por medio de una lectura del trívium medieval: históricamente, dice, la lógica y la gramática dominaron el campo de las ciencias en detrimento de la retórica, hasta que, con la lingüística, la retórica dio «un golpe de Estado», revelando que detrás de todo armado lógico hay un sofista. Podríamos decir que la teoría consiste en ocupar el umbral del lenguaje, es decir, en pensar en/desde los límites formales de la palabra dicha o escrita.'

Esto tiene una serie de consecuencias centrales. La primera de ellas es que la teoría presenta una posición ética. Podemos pensar el tema comparándolo con la propuesta que Jacques Lacan hace en La ética del psicoanálisis. En ese seminario, Lacan elabora una visión radical de la ética que se resume en la siguiente pregunta: «¿Ha actuado usted en conformidad con el deseo que lo habita?» (2000:373). La ética del psicoanálisis no consiste en volver a los instintos primordiales. De lo que se trata, más bien, es de abandonar los objetos en los que el individuo se ha enredado para descubrir la pureza del deseo que lo sostiene. Por supuesto, es una exigencia descomunal, que Lacan sintetiza diciendo que «en cada uno de nosotros, existe la vía trazada para un héroe y justamente la realiza como hombre común» (380). Sólo el héroe puede seguir el verdadero camino del deseo, porque la ley moral pide que uno no se conforme con los objetos habituales que encontramos en la realidad, sino que exige llevar las cosas más allá, no ceder en el deseo, es decir, encontrar el deseo en toda su dimensión y pureza, deseo que apunta a un objeto que se define por desaparecer. La ética sería intentar el camino del héroe, como Antígona y Edipo, no conformarse con el del hombre común. Si trasladamos la cuestión al ámbito de la teoría, podemos decir que el umbral teórico también establece una ética de este tipo: la lectura no debe cerrar un texto cristalizando una interpretación, de la misma manera que el deseo no tiene que conformarse con objetos cristalizados, sino que tiene que mantener su apertura, es decir, el elemento siempre inquietante que conmociona la clausura del sentido.

Esta ética tiene referentes célebres, como Maurice Blanchot, lo que permite que nos concentremos en unos pocos y conocidos ejemplos argentinos. ${ }^{2}$ En primer lugar, quisiera recordar a Josefina Ludmer. En «El resto del texto», un conocido ensayo aparecido en la revista Literal en 1973, Ludmer comienza diciendo que "Una vez "formalizado" el texto e inscripto en una cierta teoría queda un resto no totalizable» (81). ${ }^{3}$ Ese resto tiene consecuencias variadas, la más importante de las cuales es que «rompe la impenetrabilidad de todo "modelo crítico" y de toda "aplicación"» (81). A partir de esto, Ludmer propone una ética del desperdicio: «se lo llama el "desperdicio" del texto: es, en realidad, su potencia» (81). Esta potencia se basa en la imposibilidad que tiene el resto de articular un significado estable, pero también en que ese resto no es siempre el mismo, sino que es lo que cae de la estructuración simbólica de tal o cual teoría en particular. El resto es la fuga del sentido. La ética de la teoría literaria se encuentra en esos restos, porque, como dice Ludmer, «constituyen la única posibilidad de descentrar los sistemas totalizantes y teleológicos» (83) que habitualmente le dan forma a las corrientes críticas y subtienden los discursos sociales.

El segundo ejemplo al que quisiera referirme es en realidad doble. En uno de los ensayos que le dedica a Oscar Masotta, me refiero concretamente a «La búsqueda del ensayo», Alberto Giordano 
se imagina al autor de Conciencia y estructura como Blanchot a Foucault: «un hombre en peligro», es decir, alguien que está dispuesto a arriesgarlo todo en una empresa que, como la de la crítica y la teoría, se dirige siempre a un inevitable fracaso. Para Giordano, esta cuestión está ligada a que los textos se desbordan, lo que hace que la crítica y la teoría deban asumir una ética de lo inacabado y lo tentativo. Encuentra esto antes de que en Masotta se produzca el giro estructuralista (Giordano habla de la época de Sexo y traición en la obra de Roberto Arlt). En este sentido, la ética se vislumbra en la voluntad desde el principio ensayística de Masotta y en la conciencia de que el ensayo se dirige al fracaso, como lo demuestra con «Seis intentos frustrados de escribir sobre Arlt», de 1962. Si este ejemplo es doble, es porque Giordano se mira en el espejo de Masotta y coordina sus movimientos con él. En «Los ensayos literarios del joven Masotta (Primer encuentro)», otro de los trabajos que recopila en Modos del ensayo, Giordano acuerda con el autor de Conciencia y estructura: la literatura es «una experiencia que suspende el poder de comprensión», y esto, esta inconsistencia de la literatura, viene a demostrar que la crítica, si asume la ética del ensayo (la ética de la teoría), se convierte ella misma en literatura. ${ }^{4}$

Al lado del umbral teórico y de esta posición ética, quisiera destacar que la teoría mantiene una relación tensa con el poder. Hablo de poder en el sentido más extenso que se le puede dar a esa palabra: el poder dentro de las disciplinas sociales o el poder en la gestión de las universidades, pero también el poder como capacidad de dominio y convicción que tienen los medios de comunicación y el Estado. Digo que se trata de una relación tensa porque, por un lado, la teoría pueda estar articulada con el poder, por ejemplo cuando ocupa un lugar importante en las universidades, o cuando articula con el poder político, como sucedió con Giorgy Lukács durante el estalinismo; pero, por el otro lado, esta relación es tensa porque desde sus fundamentos éticos la teoría se opone al poder, sea estatal, institucional, universitario o intelectual. Con esto no quiero decir que sea siempre una propuesta revolucionaria o que haya que festejar su posicionamiento político; tampoco hablo de esas formas de la micropolítica que nadie ve ni escucha, que se dan dentro de textos que, a la distancia, incluso parecen sospechosos; con esto quiero decir, por el contrario, que si el umbral teórico define una ética, esa ética es política, en el sentido de que lo que afirma es la inexistencia de realidades más allá de los discursos y por lo tanto muestra que el poder es siempre una operación simbólica.

Para la teoría, esto tiene dos consecuencias entrelazadas. En primer lugar, a través de la literatura, pero también con ella, concentrándose en sus enunciados, la teoría se pregunta por cuestiones como quiénes son los que tienen derecho a hablar o de qué modo los lenguajes operan sobre el mundo y la sociedad al nombrar las cosas y establecer determinado tipo de ordenamientos discursivos. Esta tarea aparece en algún momento del siglo XX, tal vez con la escuela de Frankfort o, más tarde, con un texto como El orden del discurso de Michel Foucault, pero sea cual fuere el momento que elijamos, podemos decir que en algún punto la teoría se convierte en un estudio sobre los vínculos de la lengua con el poder. Primera consecuencia, entonces: la teoría es una herramienta de análisis de la dimensión política de la literatura y del resto de los lenguajes sociales. La segunda consecuencia de este movimiento está íntimamente ligada a la anterior. Si la teoría se ocupa del poder, hay que reconocer que no es ajena a los poderes que describe. Afirmar lo contrario sería una contradicción, desde el momento en que aceptamos que el poder se pone en práctica con el lenguaje. Y con esto quiero decir que las teorías literarias son formas mediante las cuales los intelectuales intervienen en el entramado de lenguajes que constituye la sociedad y responde 
a los problemas que esa sociedad presenta. En este sentido, la teoría literaria, por más específica que sea, constituye una forma de intervención en lo público. Esto permite valorar las tendencias teóricas, que no tienen nada de frívolas, porque establecen un vínculo y un posicionamiento concreto de la teoría en la sociedad.

Tomemos como ejemplo el conocido ensayo de Jacques Rancière Política de la literatura. En ese trabajo, Rancière define la política como «una esfera de experiencia específica donde se postula que ciertos objetos son comunes y se considera que ciertos sujetos son capaces de designar tales objetos y de argumentar sobre su tema» (2011:15). A partir de esta definición, rechaza la idea de que la política de la literatura está representada por la ideología de los autores y sugiere una visión molecular (en el sentido que le dan a ese concepto Gilles Deleuze y Félix Guattari) de acuerdo con la cual los escritores proponen la integración democrática de nuevos objetos y nuevos sujetos a lo público. Dicho de otro modo, para Rancière la política de la literatura se define como una operación sobre las preguntas ¿quién puede hablar? y ¿de qué se puede hablar? La tesis es aceptable o no, pero quisiera reparar en otra cosa: para proponerla, sugiere una historia de la crítica y la teoría alrededor de la figura de Gustave Flaubert.

Detengámonos primero en la crítica que, en nombre de Flaubert, Rancière le hace a Sartre. En ¿Qué es la literatura?, Sartre sostenía que cuando Flaubert poetizaba la prosa lo que hacía era dar un asalto aristocrático a la naturaleza democrática de la novela. «Flaubert, Mallarmé y sus colegas - parafrasea Rancière - pretendían rechazar el modo burgués de pensar y soñaban con una nueva aristocracia, viviendo en un mundo de palabras purificadas» (2011:21). Esto explica, para Sartre, que intervinieran poéticamente la prosa: en ese humus democrático, formaban una aristocracia de nuevo tipo. Aunque se trata de una idea convincente, Rancière la rechaza de plano: cuando Flaubert se detiene en el detalle y trabaja con preciosismo la prosa, afianza la democratización, porque borra las fronteras de los géneros, mezcla lo bajo y lo elevado y rompe con los órdenes que establecían la distribución de los cuerpos y las palabras heredados del siglo XVIII.

Si en este texto hay implícita una historia de la teoría, no es sólo porque Rancière tome a Flaubert para criticar a Sartre, movimiento que replica en «El barómetro de Madame Aubin» (2014) para atacar a Rolland Barthes, sino también porque, de manera muy curiosa, en ninguno de esos trabajos menciona a Pierre Bourdieu. En ambos ensayos, Rancière hace de cuenta que éste no existe, pero lo cierto es que Bourdieu ya había leído a Flaubert y había criticado a Sartre de una manera no menos demoledora. Por otra parte, hay que destacar que no lo hizo en algún trabajo colateral de su carrera, sino que la lectura de Flaubert y la crítica a Sartre aparecen en lo que podríamos considerar como uno de sus ensayos programáticos, «Campo intelectual y proyecto creador», originalmente publicado, no es un dato menor, en Les Temps Modernes en 1966. Si se trata de un ensayo programático, es porque es el texto al que Bourdieu vuelve una y otra vez, amplificando su alcance y precisando sus conceptos, hasta el final de su vida. ¿Por qué Rancière se desentiende de semejante ensayo? De esa pregunta no me interesa la respuesta, sino el silencio que sugiere, porque completa un triángulo en cuanto a las formas que compuso la teoría de pensar e intervenir en la sociedad.

En efecto, podríamos decir que autores como Sartre, Bourdieu y Rancière no se equivocan. En todo caso, manifiestan el tipo de relación que la literatura y la teoría mantienen con la sociedad. Por supuesto, uno puede criticar el modo acartonado con que Sartre separaba poesía y prosa, pero no podríamos considerar que se equivocó, porque lo cierto es que fue muy efectivo: se convirtió en el referente central de varias generaciones a nivel mundial. Esto indica que la teoría literaria 
no puede evaluarse a partir de la verdad o la falsedad, sino que tiene un componente pragmático, lo que daría como resultado que se pasa de una evaluación sobre la verdad a una valoración pragmática de sus efectos y sus acciones. Esto significa que interviene para marcar necesidades y propósitos y generar determinado tipo de realizaciones. Sartre piensa en una intervención directa del intelectual en la política; Bourdieu muestra que esa intervención se produce en un campo de producción cultural autónomo que conforma, junto con otros, la esfera pública; Rancière se propone salir del encierro con que Bourdieu piensa la literatura y el arte para reabrir esas producciones articulándolas de nuevo con los elementos intensos de lo social. Las teorías de Rancière, Bourdieu y Sartre son modos de comprender la relación del intelectual con lo público, y tienen un anclaje muy importante en las épocas en que aparecieron. La teoría literaria puede pensarse, en este sentido, como una forma de intervenir en lo social.

\section{Sociología de la cultura}

Aunque la tesis que acabo de proponer tiene un alcance general, creo que es particularmente útil para pensar los modos en los que funciona la teoría literaria en América Latina. Recordemos que, en nuestra región, solemos emplear las ideas que provienen de los países centrales, entre los que se destaca, por supuesto, Francia. Pero no por esto debemos concluir que existe una «colonización mental», porque si la teoría se basa en el umbral teórico, hay que reconocer que el eje nunca está puesto en los contenidos, sino en la forma en la que empleamos los textos y las ideas. Por este motivo, lo crucial es cómo usamos la teoría para analizar textos, y, singularmente, cómo la teoría interviene en lo social.

Para mostrar la plausibilidad de esta idea, voy a hacer, primero, un repaso fugaz por un tema muy conocido en Argentina. Entre los años 80 y 90 del siglo pasado, Beatriz Sarlo y el grupo de Punto de Vista propusieron una renovación teórica por medio de la incorporación de la sociología de la cultura, poniendo como referentes las obras de, entre otros, Pierre Bourdieu, Raymond Williams y Jürgen Habermas. Destinada a ocupar el centro de la escena, la sociología de la cultura marcó la agenda de los estudios literarios hasta los primeros años 2000: forjó los ejes para comprender el pasado reciente en Argentina, definió los principios básicos para el estudio de las publicaciones periódicas, le dio rigor a los estudios literarios y culturales, algo que se aprecia en el estilo, con el abandono de las derivas incomprensibles que generaron muchos deleuzeanos y lacanianos de segundo orden, y todo esto dio como resultado libros y tesis doctorales de particular importancia y actualidad. ${ }^{5}$ Este aporte teórico se desplegó en la revista Punto de Vista, pero también en un libro fundamental como Literatura/sociedad, en el que, entre otras cosas, Beatriz Sarlo y Carlos Altamirano introdujeron los principales enfoques sociológicos de la literatura y establecieron algunas de las modificaciones necesarias para su uso en América Latina. Como ejemplo, recordemos que en ese libro sientan las bases para el estudio de las publicaciones periódicas, por medio de ideas que se siguen empleando en la actualidad, y hacen una revisión de los conceptos bourdesianos, en particular de la idea de autonomía para los países latinoamericanos, que tuvo una influencia igual de decisiva. ${ }^{6}$

Pero si me refiero a la sociología de la cultura en Argentina, es sobre todo porque ese enfoque puede comprenderse como una forma de intervención de la teoría en lo social. En ¿Quién de nosotros escribirá el Facundo?, José Luis de Diego demuestra que, en los años 80, Sarlo y buena parte del grupo de Punto de Vista abandonaron las posiciones revolucionarias de los 70 y comenzaron a 
articular con el proceso democrático iniciado en 1983. Los autores que fueron incorporando desde entonces, en especial Bourdieu, Williams y Habermas, son cruciales para este giro, porque los tres se ocupan de la conformación de la esfera pública, una cuestión central en el proceso de democratización que se inicia en 1983. ${ }^{7}$ En «La moda y "la trampa del sentido común". Sobre la operación Raymond Williams en Punto de vista», Miguel Dalmaroni demuestra la existencia de este vínculo por medio de un agudo análisis sobre el rol que ocupa en la revista el autor de Marxismo y literatura. Para Dalmaroni, Williams les permitió a los de Punto de Vista contrarrestar la moda formalista, proveniente del tándem estructuralismo-posestructuralismo-Tel Quel, y les dio la posibilidad, asimismo, de pensar los vínculos entre cultura y política en el sombrío clima de la última dictadura militar. Pero también, agrega Dalmaroni, Williams les permitió «encontrar un foco teórico novedoso que, sin abandonar del todo el programa de crítica de la cultura elaborado poco antes en la revista Los libros, permitiera abandonar el marco político que había funcionado como justificación de ese programa» (2). En este sentido, los intelectuales de Punto de Vista (o bien la mayoría de ellos) importaron a Williams porque con él podían dejar atrás el telos de la revolución como organizador del pensamiento e intervenir en el proceso democratizador sin salir de la órbita del marxismo. Como agrega Dalmaroni en la parte polémica de su ensayo, el Williams que permitió esto es el Williams tamizado por las necesidades teóricas y políticas de Punto de Vista. Si extendemos este análisis a otras de las figuras de la sociología de la cultura, podemos decir que la revista importa, y al mismo tiempo transforma, a autores como Williams, Bourdieu y Habermas, en la medida en que sus propuestas permiten pensar y al mismo tiempo construir una esfera pública por medio del desarrollo de las expresiones culturales dentro de la sociedad civil.

No hay texto que caracterice de mejor manera esta trama que «El campo intelectual: un espacio doblemente fracturado». Beatriz Sarlo lo presentó en el coloquio de Maryland Represión y reconstrucción de una cultura: el caso Argentino, coordinado por Saúl Sosnowski, en 1984. Escribe lo siguiente al principio de su comunicación:

Es claro que algunas de las preguntas que, subterráneamente, atraviesan este escrito, tienen que ver con un interrogante difícil de responder en los años de la dictadura militar, pero cuya resolución ocupará, quizás, el resto de nuestras vidas: cómo éramos nosotros, los intelectuales jóvenes de la Argentina, en los años setenta; sobre qué tipo de sujetos y de relaciones intersubjetivas se ejerció el poder autoritario y la violencia. (95)

Sarlo habla en primera persona porque se propone estudiar la estructura de sentimientos (cita explícitamente a Williams) que caracterizaba la época. Es decir, busca reconstruir esa combinación de vanguardia y politización, peronismo e izquierda, sofisticación intelectual y popularismo, que en la época no estaban estudiados ni discernidos de manera sistemática, sino que eran ideas e incluso contradicciones que vivían las personas. Pero más allá de esta motivación teórica, estas palabras, leídas en la actualidad, son proféticas. En rigor, Sarlo está identificando los problemas que marcarán la agenda de los estudios literarios y culturales de las próximas décadas y los ejes teórico-metodológicos desde los cuales se puede desarrollar la tarea. Es así que, en 1984, Sarlo compone un programa de trabajo en el que propone un objeto de estudio, la cultura de los años 60 y 70, un corpus literario e intelectual abultado pero con lineamientos concretos, y un armado teórico cuyos autores principales son Williams, Bourdieu, Benjamin y Habermas. 
Aunque se trata de una propuesta historiográfica, todo este armado teórico y literario está referido a la actualidad. Podemos verlo recordando los propósitos con los que Saúl Sosnowski había convocado al coloquio. Esos propósitos se encuentran en el título: Represión y reconstrucción de una cultura: el caso argentino. Es decir, el objetivo es reconstruir la sociedad por medio de un giro democrático, pero sobre todo, subraya Sosnowski en la introducción y en la invitación al evento, se trata de darle nueva vida a la sociedad civil (emplea explícitamente ese concepto) y al diálogo como una herramienta crucial de renovación política y cultural. Sarlo se incluye en esta propuesta identificando como principal tarea la recuperación de la identidad de los intelectuales. Esta tarea, agrega en su trabajo, tiene como plataforma la conciencia de la crisis en la que entraron las utopías revolucionarias y tres objetivos centrales: 1. volver a establecer un discurso y una práctica públicos, 2. repensar la política de manera global, y no sólo en los términos de represión y terror y 3. recuperar medios y espacios materiales de producción discursiva y simbólica. En otras palabras, la relectura de los años 60 y 70 significa para Sarlo la reconstrucción de una esfera pública, es decir, la recreación de un espacio de discusión democrático que surge y está dirigido por la sociedad civil y facilitado por los espacios públicos previamente democratizados, como la Universidad. Al articular a Habermas, Williams y Bourdieu Sarlo propone, entonces, una perspectiva teórica para contribuir desde el campo intelectual a la reconstrucción de la democracia.

\section{Diáspora(s) I: la teoría y la guerra}

$\mathrm{Si}$ la tesis de que la teoría literaria interviene en lo social es correcta, debería servir para pensar ámbitos distintos del argentino. No porque la Argentina no sea un país lo suficientemente rico como para abordar el tema, porque desde luego lo es, como acabo de sugerirlo, sino porque una tesis predice comportamientos, independientemente de las particularidades locales que esos comportamientos puedan tener, de modo que sería razonable ponerla a prueba en otros ámbitos culturales. Como en un trabajo como este sería imposible tomar un grupo importante de países, tal vez se puedan situar algunos puntos de referencia. Ya que tomé en la primera parte ejemplos argentinos, quisiera completar un panorama mínimo con otros que se encuentran en Cuba. Con esto propongo abrir un espectro, porque Argentina y Cuba tienen la rara condición de mantener una serie de vínculos importantes, desde Ernesto Guevara a Virgilio Piñera, pasando por el neobarroco, que cristaliza en Caribe trasplatino, de Néstor Perlongher, ${ }^{8}$ pero a la vez son países que están muy alejados geográficamente y configuran, de alguna manera, antípodas culturales, como se desprende del hecho de que Argentina es un país continental, mientras que Cuba es uno insular.

Estas diferencias se profundizan al tomar en cuenta la política. Desde los años 80, Argentina se enmarca en una democracia de estilo moderno, más allá de los vaivenes y las conocidas dificultades que se produjeron desde esa fecha a la actualidad. Esto significa que durante todo este tiempo fue abandonando las pautas totalitarias que, durante buena parte del siglo XX, organizaron lo político en todas partes del globo, aunque de manera muy particular en América Latina, durante la Guerra Fría. En la misma época, Cuba mantiene, en cambio, un sistema basado en un partido único, con un fuerte control de la palabra pública, lo que significa que es el Estado el que define qué sujetos y qué objetos participan delo político y lo cultural.

Por supuesto, elegir un solo país no soluciona los problemas, porque un país tiene realidades estéticas, políticas y culturales muy complejas y variadas. Por esa razón, en lo que respecta a Cuba, me voy a concentrar en un fenómeno puntual, que es la tensión que existe, a fines de los años 9o, entre 
los intelectuales disidentes y el Estado. Esto se debe a que se trata de un problema que se puede estudiar incluso abordando la trayectoria de un solo escritor, pero también a que es un fenómeno que tiene una significación que va más allá de lo cubano. Para verlo, recordemos que, en Espectros de Marx, Jacques Derrida dice con justa razón que la caída del muro de Berlín no afecta sólo a los países socialistas, sino que afecta a todos, porque las consecuencias son claras: el capitalismo avanza hacia el modo neoliberal. En igual sentido, la tensión cubana entre el oficialismo y la disidencia genera una saturación teórica en la que pujan un orden político tradicional con formas de organización política, intelectual y estéticas típicas de la posmodernidad. Aunque esta tensión es local, advierte sobre cuestiones que van más allá de las fronteras nacionales. Para evaluar esto, como problemática cubana, pero también por sus implicancias globales, me voy a detener en la revista Diáspora(s).

La publicación es la experiencia principal que realizaron varios de los que se convertirían con el tiempo en los principales escritores cubanos de los años 9o. Diáspora(s) estaba coordinada por Rolando Sánchez Mejías y Carlos Aguilera, y entre los colaboradores ocuparon un lugar destacable, aunque por supuesto no excluyente, Rogelio Saunders y Pedro Marqués de Armas. El grupo optó por una política de los márgenes, es decir, rompió con las condiciones gubernamentales de la palabra pública con el propósito de desarrollar formas propias de pensar y practicar la literatura. Esta marginalidad no es una metáfora: la revista se publicaba en fotocopias (hoy en día la conocemos gracias a la edición facsimilar que preparó Jorge Cabezas Miranda en 2013). ${ }^{9}$ Por ese motivo, no tenía sello oficial, no se podía vender y, en consecuencia, gravitaba desde afuera de la palabra pública. A causa de esto, autores como Gerardo Muñoz, Carmen Paula Bermúdez y Todd Ramón Ochoa la han caracterizado, directa o indirectamente, como un samizdat, es decir, como los textos prohibidos, que circulaban de mano en mano en la Unión Soviética. ${ }^{10}$

Si bien se trata de una revista que tiene múltiples intereses, lo central en este contexto es que propuso una importante renovación teórica por medio de la publicación de textos de autores extranjeros (muchos de ellos fueron traducidos por colaboradores de la revista). La presencia y densidad de este tipo de trabajos es notoria. En los seis números que salieron (vale aclarar que dos de ellos son dobles) aparecieron: un ensayo de Jacques Derrida sobre poesía, un apartado del libro de Peter Sloterdijk sobre el cinismo, una entrevista de Tony Negri a Gilles Deleuze sobre las sociedades de control, una conversación radial entre Theodor Adorno y Elías Canetti sobre las masas, un texto de Milan Kundera sobre la burocracia y una conferencia del poeta ruso Joseph Brodsky. Aunque no son referencias teóricas en sentido estricto, cabe agregar también unos poemas de Hans Magnus Enzerberger, en los que el escritor alemán, radicado en La Habana en los años 60, expresa su desengaño respecto de la revolución, y un ensayo de Thomas Bernhard, en el que se refiere con duros términos al poder gubernamental.

Si en Argentina una buena parte de los esfuerzos teóricos se volcaron a reflexionar sobre la esfera pública, Diáspora(s) muestra que, en Cuba, uno de los nudos de la reflexión teórica se encuentra en el tema del poder. Aunque hay muchas diferencias entre los teóricos que traducen y publican en sus páginas, podemos decir que la revista se basa en las ideas de Deleuze y Foucault. En la entrevista que le realiza Tony Negri, que Diáspora(s) publica en el número 3 (septiembre de 1998), Deleuze hace su conocido deslinde entre las sociedades disciplinarias y las sociedades de control. Allí reconoce que la idea le pertenece a Foucault. En Foucault existen, en efecto, dos concepciones fundamentales del poder." La primera la desarrolla en Vigilary castigar y La voluntad de saber y en el curso Defender la sociedad. Allí, pone el acento en la forma disciplinaria y comprende el poder 
por medio de la metáfora de la guerra. En Defender la sociedad lo dice con su conocida inversión del aforismo de Clausewitz: no debemos ver la guerra como continuación de la paz, sino la paz como continuación de la guerra. En Tecnologías del yo, denomina a esta una «tecnología del poder» (2008:48-49), y hay que entender que se refiere a una lógica poder/resistencia en la que se busca el sometimiento del adversario. Después de un período crítico, Foucault desarrolló una nueva mirada sobre el tema en los cursos Seguridad, territorio y población y Nacimiento de la biopolítica, investigación que culmina en los últimos dos tomos de Historia de la sexualidad. En esos trabajos, se ocupa de una tecnología distinta, que no opera sobre el individuo, sino sobre la población, y que comprende con el nombre de «tecnologías de gobierno». Foucault se enfoca en la resistencia del individuo al sometimiento, lo que le permite plantear cierto margen de libertad. Por ese motivo, la tecnología de gobierno no busca someter, sino convencer: no ejerce una presión sobre el individuo para normalizarlo, sino que trabaja con los deseos, es decir, con lo que Deleuze comprendería como la condición abierta y nunca llena del individuo. En nuestras sociedades tenemos un ejemplo vivo: dentro de ciertos parámetros, el poder no nos encarcela, sino que nos maneja a partir de nuestros deseos. Creemos que amamos nuestro trabajo, que es hermoso tener hijos, que elegimos determinados productos y votamos libremente por tal o cual candidato, cuando en realidad somos manejados por las tecnologías gubernamentales. Las redes sociales y el marketing son las nuevas formas de la organización política y la manipulación social.

Como se enfrenta a un Estado que controla de manera fuerte la vida pública, Diáspora(s) piensa la situación cubana por medio de la primera visión del poder que propone Foucault. Por este motivo, la revista compone lo que podemos llamar una retórica de la guerra. Esta retórica se desarrolla en todos los niveles: en el nivel ideológico general, Diáspora(s) propone un espacio disidente que lucha contra el Estado; en el nivel de la discusión intelectual, los escritores confrontan con los intelectuales oficialistas (a los que caracterizan como traidores, cínicos o intelectualmente limitados: son hablados o se dejan hablar por la lengua del poder); en el nivel de la escritura, los autores utilizan muchas veces metáforas o formas de comprensión bélica y se inclinan por un estilo firme y resistente a una lectura liviana.

Hay tres ejemplos destacables de este proceder. El primero se encuentra en la nota de presentación: se trata de una serie de sentencias firmada por Sánchez Mejías, en uno de las cuales hace la siguiente declaración: «Diáspora(s): un Grupo (?). Una avanzadilla (sin)táctica de guerra» (176). ${ }^{12} \mathrm{El}$ mismo Sánchez Mejías dice en un texto sobre Orígenes: «Un escritor, para sobrevivir como escritor, necesita representar un papel en la República de las Letras: y así arma su escenario, que incluye el desencuentro, el equívoco, la batalla» (190). Por último, en «El lenguaje y el poder» ( $n^{\circ} 6$, de 2001), Rogelio Saunders retoma la inversión del aforismo de Clausewitz: «Hace poco le dije a alguien con quien conversaba: Cuando terminan las palabras, comienza la lógica de la guerra. Pero no es cierto: la lógica de la guerra está contenida ya en las palabras» (494).

En Diáspora(s), la teoría del poder tiene su mejor desarrollo en este ensayo de Saunders. En esa oportunidad, Saunders propone la tesis de que el poder no es una fuerza externa que comunica sus órdenes por medio del lenguaje, sino que es inmanente al lenguaje mismo. No hay dictador sin dictado, podríamos decir, lo que indica que los dictadores son manifestaciones del acto de dictar. De clara inspiración focuaultiana, la idea se inscribe en los análisis sobre el orden del discurso, es decir, el discurso como orden y ordenamiento. En la Lección inaugural, Roland Barthes avanza en este sentido al señalar que la lengua es fascista. Recordemos sus argumentos: «No vemos el 
poder que hay en la lengua porque olvidamos que toda lengua es una clasificación, y que toda clasificación es opresiva: ordo quiere decir a la vez repartición y conminación» (118). Barthes cita a Jakobson: «un idioma se define menos por lo que permite decir que por lo que obliga a decir» (118). Por eso, «la lengua, como ejecución de todo lenguaje, no es ni reaccionaria ni progresista, es simplemente fascista, ya que el fascismo no consiste en impedir decir, sino en obligar decir» (120).

Saunders retoma esta idea y la inscribe en la lógica de la guerra. Pero hay que destacar que la tesis también tiene una raigambre latinoamericana. No digo que haya en su texto influencias directas, porque no menciona ninguna, pero, como ha demostrado Raúl Antelo en Archifilologías latinoamericanas, los textos traman vínculos y generan afectaciones que van más allá de las lecturas directas o las citas y discusiones explícitas, de modo que componen una «vasta Biblioteca contradictoria» (264). Así, podemos decir que en las palabras de Saunders se escucha La ciudad letrada de Ángel Rama: ¿quién no leyó ese libro y no se dejó influir en algún aspecto por él? En Argentina, esta temática de la lengua/poder entró antes de Foucault, a través de Lacan. Tenemos un ensayo central como "El matrimonio entre la utopía y el poder», publicado en la revista Literal en 1973: escrito por Germán García y Osvaldo Lamborghini, el texto propone una lectura lacaniana del peronismo y se adelanta a las teorías posfundacionales sobre lo social. Aunque las tesis centrales las escribe en Inglaterra, en esta línea también se encuentra Ernesto Laclau, quien, en colaboración con Chantall Mouffe, publican Hegemonía y conciencia socialista, en el que los autores proponen un nuevo cruce entre marxismo y psicoanálisis, por medio del cual conciben la sociedad como una serie de lenguas en disputa, sobre las cuales se pueden levantar articulaciones y subordinaciones sintácticas mediante las cuales construir una hegemonía.

Aunque el ensayo de Saunders, y la revista en su conjunto, piensan el poder de acuerdo con la lógica de la guerra de Foucault, desarrollan una lectura sobre el lenguaje/poder que se mueve con libertad y con la que afianzan esta forma de pensar muy arraigada en América Latina. Leamos el siguiente fragmento de su ensayo:

La palabra, entonces, es el poder (en todo el sentido que puede tener esta palabra, que acaba siendo estrecho y de una lógica implacable), porque es el Pragma mismo. Y sobre este poder del Nombre está construida toda la complicada estructura social dentro de la que vivimos; y dentro de la cual, como expresión máxima de lo que puede hacer el Nombre, florecen los Dictadores, hongos últimos cuya retórica está tan llena de veneno como de pompa. (494)

Subrayemos la progresión de Saunders. El nombre es poder, pero no podemos vivir sin el nombre, lo que quiere decir que una sociedad no puede subsistir sin una serie de nombres compartidos. Desde la manada primitiva al nazismo, todo consiste en articular uno o más lenguajes. Para decirlo con Laclau y Mouffe (Hegemonía y conciencia socialista), toda sociedad se define por la existencia de significantes flotantes y puntos de capitonado que sueldan los significantes a significados estables. Esto compone lo que designamos habitualmente como realidad: una red de objetos, acciones y sujetos que tienen un sentido que todos más o menos reconocemos. Para Saunders, el totalitarismo no es algo que viene de afuera, sino que es el intento de clausurar la producción de sentido por medio de una lengua semánticamente cristalizada. Escribe sobre esta cuestión: «el Poder querría (el poder totalitario, eminentemente) que las cosas significaran una sola cosa» (490). Enseguida añade: «Que los signos sólo señalaran hacia un solo lugar: hacia donde está el ersatz 
del cielo adorable, del radiante sol y de las infinitas columnas de hombres que marchan al futuro» (490). Esto lo lleva a destacar que lo propio del totalitarismo no es el silencio, sino el lenguaje. «El lenguaje es, por así decirlo, el aire que se respira en un Estado Totalitario. Todo está lleno de cifras, de nombres, de consignas. De exhortaciones a la tarea y/o de cantos de guerra y de victoria» (490). Esta fiebre está hecha para controlar los significados: «El Partido —el Partido Único, creado para "mantener y salvaguardar la Unidad Nacional" — es precisamente la legalización de la Nomenklatura (del gobierno de los Nombres)» (495).

Por medio de estas interpretaciones, Saunders se acerca a Deleuze y Guattari. Para el escritor cubano, como en general para la revista, el estado es molar: lo mueve una paranoia por la que busca sentido en cada signo e intenta definirlo de una manera unívoca, controlando su proliferación. La literatura, en cambio, es molecular: rompe y desplaza los códigos, deconstruye las articulaciones, hace proliferar los sentidos. La revista aboga por una literatura, o mejor: por una lengua menor. Esta acción está inscripta en la materialidad de la revista, hecha de fotocopias, que salen de alguna máquina que inevitablemente tiene que pertenecer a una oficina de la burocracia estatal. Esto significa que, más allá de si formula o no propuestas teóricas, Diáspora(s) produce una acción teórica de intervención en lo social, porque vuelve al umbral de los significantes abiertos y los conecta con una trama abierta de significación. Compone, por lo tanto, una retórica de la guerra y las lenguas menores.

\section{Diáspora(s) Il: la guerra, el ajedrez y el go}

Esta intervención teórica tiene una particular importancia en los textos en los que la revista toma posición sobre Lezama Lima y la revista Orígenes (1944-1956). Como se sabe, los intelectuales orgánicos a la revolución, muchos de ellos importantes colaboradores de esta revista, como Cintio Vitier y Fina García Marruz, profundizaron en los años 80 la articulación del mesianismo católico de Lezama con la revolución. Para esto, continuaron algunos ensayos del escritor, como "Lectura» (1959) [1981] y «A partir de la poesía» (1960) [1975], en los que este manifiesta que aquello que en los años 40 y 50 se podía ver como una imagen utópica de realización nacional había finalmente arraigado el $1^{\circ}$ de enero de 1959 , produciendo una nueva y definitiva era imaginaria. ${ }^{13}$

Esta lectura de la obra de Lezama tiene uno de sus momentos centrales en el dossier que le dedica Casa de las Américas en 1985. Se trata de un año clave: muerto hacía 9 años, Lezama habría cumplido 75. En la presentación, sin firma, Casa de las Américas establece una posición política sobre el escritor:

Cuando hablamos del respeto con que su tarea y su persona fueron rodeados a partir de 1959 por la Revolución Cubana — preludios del reconocimiento mundial de su obra - no es posible eludir varios hechos. En primer lugar, que supuestamente a nombre de la Revolución Lezama fue pronto objeto de ataques groseros, que a veces no eran sino la continuación de ataques previos y se reiteraron en una olvidable noche de 1971. Quienes los lanzaron, son hoy enemigos feroces («endemoniados jabatos» los hubiera llamado Lezama) de la Revolución tras cuya máscara se escondían. En segundo lugar, que, según afirmó de él mismo Lezama, «es verdad como se dice que he sido en la cultura cubana un valor muy polémico, pero esa manera sigue siendo como una ley de corsi y ricorsi. Cuando se me ha negado con furia yo he sabido esperar trabajando y sonriéndome, y poco después ha llegado el ricorsi, el acercamiento amistoso, el reconocimiento y el estudio de mi obra». Esta observación ha sido válida aplicada a personas de muchos matices. Pero estamos 
seguros de que el feliz ricorsi que conoce la producción de Lezama no será seguido de un nuevo e injustificado corsi. Lezama pertenece ya a los clásicos, en el orden literario; pertenece a nuestra tierra: la tierra de nuestra patria, de nuestra cultura, que alcanzan incandescencia con la Revolución. (2-3)

Al principio, la nota alude a la confesión que hace Padilla en 1971, tras salir de la cárcel, en la que denuncia a Lezama como contrarrevolucionario. De una manera poco justificada, Casa de las Américas culpa a Padilla, y no al Estado, por el silencio y el ostracismo en el que vivió los últimos años de su vida. Pero no es en esto en lo que quiero poner el foco, sino en una cuestión de retórica. Centrémonos en las oraciones finales, en las que se produce una cadena de transformaciones, como si fueran negaciones hegelianas: la tierra se transforma en patria y la patria en cultura, para fundirse, incandescentes, en la revolución. La idea de que la revolución produce incandescencia es una metáfora. Esa metáfora, recordémoslo, está muy ligada a las apreciaciones de Lezama Lima. Al final de «A partir de la poesía» sostiene que, gracias a la Revolución, Cuba da la mayor luz que puede dar un pueblo en la tierra ${ }^{14}$ En esa luz, la religiosidad de Lezama y la razón histórica del socialismo se conjugan. Pero la metáfora le da, al mismo tiempo, una autonomía vitalista a la revolución. Deja de ser un acontecimiento realizado por hombres y mujeres y se convierte en algo autónomo, que está por encima de las personas. Desde ahí, la nota puede articular la tierra, la patria, la cultura y la obra de Lezama, porque es el momento de la iluminación final, fuego en el que todo se funde para ser creado de nuevo. La revolución es la gran metáfora que articula la tierra, el pueblo, la nación y la cultura. Por esa razón, podemos decir que la metáfora articula el catolicismo de Lezama, la revolución cubana y la nacionalidad. Y esa articulación se basa en que debajo de estas tres cuestiones se encuentra una conceptualización mesiánica del tiempo. La metáfora de la revolución, que todo lo aglutina, es en este sentido una suerte de síntesis de la forma moderna de organizar la cultura, la política y la sociedad, en la medida en que totaliza por medio de la nación, el mesianismo y la utopía revolucionaria.

Diáspora(s) le dio una enorme importancia a esta cuestión. Podemos comprobarlo en que todos los números tienen algún texto sobre Lezama y Orígenes. Más aún: casi todos tienen ensayos extensos y centrales, mediante los cuales la revista rompe con duros términos tanto con la interpretación oficial como con la que propone Lezama para apoyar la revolución. Vale la pena detenerse, en este sentido, en «Olvidar Orígenes» y «Orígenes y los ochenta» de Rolando Sánchez Mejías y Pedro Marqués de Armas, ambos publicados en el número inicial. ${ }^{15}$

Los dos abordan de una manera directa el apoyo de Lezama a la revolución. Esto significa que encuentran una relación coherente entre la interpretación que el escritor hace de ese acontecimiento y la obra que publica en los años 40 y 5o. Por esa vía, le dan parte de la razón al oficialismo: la propuesta de Lezama de una tradición por futuridad tenía que llevar al apoyo a la revolución. Pero si subrayan esta coherencia, es para expresar su más firme rechazo. No están en contra de una política puntual, sino que impugnan la base misma del origenismo y la revolución: impugnan la concepción mesiánica del tiempo que muchos intelectuales y la mayoría de la población compartía en los años 50 y que se volvió central para la revolución. ${ }^{16}$ Escribe Sánchez Mejías:

Para alguien cuya experiencia vital completa haya coincidido con la actual experiencia política de modernidad perversa que es este país, para alguien cuya experiencia vital haya sido decidida a favor del animal político a que han sido reducidos los hombres de este país, sabrá lo problemático de aceptar que 
su tiempo es la encarnación suprema de una imagen. Aquello que para Lezama y para Vitier fue un corte o fulminación o consecuencia de la Historia, fue para otros hombres el dolor de la historia en sus propios cuerpos. Lo que para ellos fue la cifra alquímica de la Historia, fue para otros la marca secreta y a la vez impúdica de la violencia de la historia en sus cuerpos. (192)

En estas palabras hay que subrayar la precisión con la que Sánchez Mejías maneja el concepto lezamiano de imagen y el modo polémico con el que se apropia de las metáforas que emplean o emplearían los origenistas. Expone con amarga ironía que lo que para el origenismo es «corte o fulminación o consecuencia de la Historia», para las personas nacidas dentro de la revolución es dolor, lo que para los primeros es la "cifra alquímica de la Historia», para los segundos es una metáfora que se labra gracias a la violencia que se ejerce sobre sus cuerpos. La revolución triunfa como una metáfora. Lo mismo dice el editorial de Casa de las Américas. Pero Sánchez Mejías agrega: esa metáfora define el conjunto de la cultura por medio de los cuerpos que se inmolan en el altar de la historia. En el mismo sentido se pronuncia Pedro Marqués de Armas en su ensayo: los origenistas postulaban «las imágenes que operan por futuridad en la historia. Nosotros con la turbiez de los negativos, y situados ya dentro de esa historia, ahora real que según el propio Lezama había igualado por obra de una Metáfora Suprema, resurrección a revolución» (194).

Pero si bien rompen con Orígenes y la revolución, los escritores de Diáspora(s) diseñan una operación mucho más compleja y sutil. Como lo revela la obsesión origenista que tiene la publicación, trabajan más bien como un ejército que invade el legado origenista para hacerlo estallar desde adentro. Para comprender este movimiento, tamicemos sus ideas con las que Deleuze y Guattari proponen para pensar la guerra.

En «Tratado de nomadología: la máquina de guerra», Deleuze y Guattari componen una interesante oposición entre el ajedrez y el go. El ajedrez, dicen al principio del tratado, «es un juego de Estado. Las piezas están codificadas, tienen una naturaleza interna o propiedades intrínsecas, de las que derivan sus movimientos, sus posiciones, sus enfrentamientos» (360). Ese juego «es claramente una guerra, pero una guerra institucionalizada» (361). Podríamos decir que la imagen que Diáspo$\mathrm{ra}(\mathrm{s})$ tiene de su oponente está labrada con la lógica del ajedrez. Para ellos se trata de un Estado en el que cada uno cumple una función, con una burocracia, y desde luego con intelectuales orgánicos. Lo mismo vale para la imagen que tienen del origenismo. En varias oportunidades, Lezama habló de reyes (uno de sus poemas más recordados se titula «Sacra, católica majestad») y concibió la organización de la cultura por medio de un sacrificio o un retorno: el modelo de Jesucristo siempre estuvo presente, cuando habló de su padre, cuando habló de Narciso, cuando habló del mulo en «Rapsodia para el mulo», cuando habló de Martí y cuando habló de la revolución. ${ }^{17}$ Como en el ajedrez, el elemento que ordena y le da sentido al resto, es decir, el rey, es una metáfora: es el símbolo del jugador en el tablero, de la misma manera que un rey es la metáfora de Dios en la tierra. El ajedrez resume el tipo de organización de la política, la literatura y la cultura que podemos juzgar tradicional a fines del siglo XIX. A este tipo de organización jerárquica de la guerra y el Estado, Deleuze y Guattari le oponen la lógica del go. «Los peones del go, por el contrario, son bolas, fichas, simples unidades aritméticas, cuya única función es anónima, colectiva o de tercera persona». Por eso «son los elementos de un agenciamiento maquínico no subjetivado, sin propiedades intrínsecas, sino únicamente de situación» (360-361). Esto hace que el go pueda comprenderse como «una guerra sin línea de combate, sin enfrentamiento y retaguardia, en último extremo, sin batalla» (361). 
Ni Sánchez Mejías, ni Marqués de Armas ni Diáspora(s) rechazan Orígenes, sino que invaden el territorio ajedrecístico, ultracodificado, de Lezama, la cultura oficial e incluso la esfera pública intervenida por el Estado, y dinamitan o intentan dinamitar esos ámbitos por medio de una operación semejante a la del go. Escribe Marqués de Armas en el párrafo final de su texto sobre Orígenes:

La ficción y la calidad de la escritura de Orígenes permanecen inalterables, no así los ideologemas derivados del Sistema Poético. Este viene a retroinyectar un componente molar-paranoico (no aludo a la clínica) en una escritura que muchas veces opera procesualmente, en los márgenes de un espacio que la representación jerarquizó. «El sistema poético funciona, luego es». Pero este es al mismo tiempo lo disfuncional, aquello que en modo alguno funciona para los demás. Ironías del artefacto: antisistemas del esquizo. Sin embargo Lezama — embaucador - deviene Gran Paranoico y lo echa a andar. Lezama pone en boca del Ángel de la Jiribilla esta frase que traduce, por sí sola, la regresión del Sistema: «Ángel, repite: Lo imposible al actuar sobre lo posible engendra un posible en la infinitud». Esta frase acontece en una fecha clave para nosotros. Rostridad, año cero. Habana, 1959. (194)

Marqués de Armas rechaza lo molar-paranoico del sistema poético lezamiano, porque lleva al sacrificio histórico (el escritor dice esto con una frase que toma, sin decirlo, de Aun de Lacan: «toda una "Regulación del alma por su escopia" donde el goce-martirio es la única historia que narra» -194-). ${ }^{18}$ Pero «La ficción y la calidad de la escritura de Orígenes permanecen inalterables», porque los origenistas plantearon una unidad entre poesía y vida que da como resultado «una escritura que muchas veces opera procesualmente, en los márgenes de un espacio que la representación jerarquizó». Esta es, también, la lectura de Sánchez Mejías. Orígenes se opuso tajantemente al realismo, el mismo que habría de copar la escena desde los años 70, y creó en su reemplazo la tradición del libro. Para Sánchez Mejías, los origenistas hicieron del lenguaje una extensión de sus cuerpos, creando una «noción abierta de la escritura —a la vez moderna y romántica - [que] tiene una importancia tremenda para escritores que quieren tener con las palabras una relación orgánica» (191). Contra la estatización ajedrecística de Lezama, Sánchez Mejías reivindica las partículas y los movimientos, toda una multiplicidad que designa por medio de la palabra "protoplasmática», que ya había empleado Lezama en «Señales», «desde la cual es posible continuar escribiendo» (190). Olvidar Orígenes significa invadirlo y destruir sus jerarquizaciones.

Es así que, en Cuba, la teoría literaria se desarrolla, al menos desde Diáspora(s), como una retórica de la guerra mediante la cual los autores operan sobre la estructura ultracodificada de los lenguajes sociales y la sobrecodificación de lo gubernamental. Como en la Argentina de los mismos años, la teoría es una forma de intervención en lo público, pero en este caso se trata de invasión y desarticulación de la hegemonía y, más aún, del tipo de hegemonía que puede concebir la modernidad. El nombre de la revista es sugestivo en este sentido. Podemos verlo como una oposición a Orígenes: Diáspora(s) es, al contrario, una huida. Es molecular, no molar, a la vez múltiple e individual, es la masa de Elías Canetti, que huye del peligro, disparada a no se sabe qué lugar. ${ }^{19}$ Diáspora(s) practica una desterritorialización de Orígenes: rompe con la cultura oficial y la palabra pública, con el lenguaje y el ajedrez, se forma en un espacio marginal, clandestino, con fotocopias y distribución de mano en mano, una supuración de lo escondido, hecha, sin embargo, con la suficiente desfachatez como para generar alarmas, provocando a la institución y el canon, desde un espacio prohibido y combativo. El go contra el ajedrez, la manada contra el Estado. 


\section{La teoría, la modernidad y la posmodernidad}

En los años 9o, Cuba y Argentina muestran formas distintas de gestionar la palabra pública. Más allá del interés intrínseco que tienen estas diferencias, en este trabajo son significativas porque nos permiten comprobar que la teoría literaria es una forma de intervención en la sociedad. Por supuesto, esta intervención aplica de una manera específica a la agenda de las investigaciones y las escrituras, pero la teoría es mucho más que una agenda universitaria. La importancia que adquieren la sociología de la cultura en Argentina y los análisis sobre el poder en la Cuba de la misma época se explican porque intervienen en los nudos problemáticos de la sociedad. De alguna manera, podemos decir que las dos perspectivas trabajan lo mismo, independientemente de que lo realicen desde ángulos teóricos distintos. Efectivamente, en los textos a los que me he referido, tanto Sarlo como Diáspora(s) afirman la necesidad de abandonar las perspectivas revolucionarias que vertebraron el siglo XX por razones que pueden resumirse en que ha perdido densidad el sustento teórico de esas propuestas. En este sentido, podríamos decir que la adopción del umbral teórico, con la saturación ética que tiene ese umbral, pone de manifiesto una posición política que consiste en dar cuenta de que esos sustentos no funcionan fuera de la historia, sino que son, como habría querido Paul de Man, operaciones retóricas y manejos de los lenguajes. Por tratarse de una revista que se encuentra en lo que podríamos llamar el ojo de la tormenta, esta cuestión adquiere una gran claridad en Diáspora(s), por lo que vale la pena detenerse en ella para terminar.

A grandes rasgos, podemos decir que la intervención política de la revista se desglosa en dos propuestas generales. La primera consiste en plantear la necesidad de terminar con el control estatal de la lengua pública. Al respecto, hay un texto muy significativo: un discurso por Thomas Bernhard para recibir un premio en 1968, que Pedro Marqués de Armas tradujo para el número 2 de Diáspora(s). Dice en un momento el escritor:

Todo esto, lo creáis o no, queráis verlo o no, tiene algo que ver con la muerte, que hable de vosotros o de mí, que seáis vosotros o yo a quien empuje al absurdo, es la muerte, estamos empujados por la muerte... que tenga algo contra los gobernantes o contra los oprimidos, contra los blancos o contra los negros, contra este gobierno por ejemplo que, como todos los gobiernos, es el peor que se pueda imaginar, contra nuestros parlamentarios, contra nuestro canciller federal, contra nuestros profesores universitarios y contra nuestros artistas, contra Heine y otros, contra Marx y otros, que tenga algo contra todos estos señores, es la muerte, es lo irreparable... es la catástrofe... todo esto, tiene algo de imposible, de inaudito. (230-231)

El reclamo de Diáspora(s) se resume en que un cubano pueda decir lo mismo sin tener que salir en fotocopias. Aparentemente, se trata de una exigencia humilde, pero tiene implicancias descabelladas, porque significa, ni más ni menos, terminar con el sistema político cubano. Con solo pensarlo unos minutos, la conclusión es inevitable: para poder insultar de este modo al gobierno, es necesario que el Estado se retire de la esfera pública. En este sentido, deberían existir medios de comunicación y editoriales privadas, y esto sería posible si aparecen partidos políticos, organizaciones sindicales opositoras y todos los elementos de una sociedad liberal. En otras palabras, Diáspora(s) pide terminar con la gestión estatal de lo público, lo que significa transformar completamente la sociedad.

Pero Diáspora(s) no hace solamente un reclamo como éste, sino que además rompe con las definiciones tradicionales de la revolución y la sociedad. Esto explica la importancia que tiene en 
sus páginas un autor como Deleuze. Más allá de que Deleuze abandona las formas tradicionales de la modernidad, ancladas en el Estado, la familia, los sindicatos, la clase obrera, la importancia del filósofo también se explica porque propone una revolución molecular de los deseos. Para enfocar esta cuestión, me parece importante citar unas observaciones de Lacan sobre el deseo en las situaciones posrevolucionarias:

\footnotetext{
Una parte del mundo — dice Lacan, refiriéndose a los países socialistas- está orientada resueltamente en el servicio de los bienes, rechazando todo lo que concierne a la relación del hombre con el deseo —es lo que se llama la perspectiva postrevolucionaria-. La única cosa que puede decirse, es que nadie parece darse cuenta de que al formular así las cosas, no se hace más que perpetuar la tradición eterna del poder -Continúen trabajando, y en cuanto al deseo, esperen sentados-. Pero poco importa. En esa tradición, el horizonte comunista no se distingue del de Creonte. (2000:378; subrayado en el original)
}

Diáspora(s) no sólo lucha por la emancipación de los deseos, sino que muestra, además, que la revolución ya no está en condiciones de postergarlos. Esto no se debe a los reclamos constantes que se producen a causa de las carencias durante el período especial; más bien se debe a que ya no existen espacios simbólicos sustentables en Cuba ante los cuales sacrificar los deseos. Efectivamente, los deseos de la época posrevolucionaria se podían sacrificar en esos altares que son la concepción mesiánica del tiempo, la formación de un sujeto colectivo, la centralidad de la nación, la formación del hombre nuevo, y todos aquellos mitos ante los cuales los individuos podían entregar su libra de carne y en este sentido obtener su circuncisión ideológica. Precisamente, Diáspora(s) dinamita ese lenguaje político-religioso por medio de la crítica destructiva que realiza sobre el apoyo de Lezama a la revolución.

Paradójicamente, esta operación de Diáspora(s) revela que los escritores que la conforman son «hijos de la revolución». Lo son, por supuesto, desde un punto de vista biográfico: nacieron cuando la revolución ya había triunfado. Pero lo son también porque el umbral teórico los lleva a presentar una voluntad de ruptura que se revela guerrillera. En este sentido, Diáspora(s) es una revista que enfrenta a un Estado atravesado por la lógica militar por medio de una táctica de guerrilla, es decir, a través de grupúsculos, invasiones y destrucciones puntuales. Como dice Guadalupe Silva, tomando las opiniones de Sánchez Mejías, la revista se propuso ir a lo micro y hacer «"guerra de guerrillas»: conmociones locales, circulación clandestina, embates sin un frente excesivamente expuesto» (150). En consecuencia, podríamos decir que, ante una realidad demasiado marcada por lo nacional y lo revolucionario, los de Diáspora(s) proponen terminar con los nacionalismos y los sacrificios, porque ya nadie cree en ellos, para pensar la sociedad como una trama de lenguajes que se mantiene unida por las contradicciones y no por metáforas incandescentes como las de Lezama y la revolución. La revista se coloca en el ámbito del pensamiento político posfundacional, es decir, en línea con pensadores como Ernesto Laclau y Jean-Luc Nancy, para quienes la sociedad no tiene un origen ni una fundación, sino que está organizada por la imposibilidad de su cierre. Trama abierta de luchas simbólicas, lo social se define como una red de lenguajes sin centro que buscan imponerse y articular con los demás.

Esto se inscribe en el título de la revista, o mejor dicho, en el juego que existe entre Diáspora(s)y Orígenes. Independientemente de las inclinaciones católicas de esta última, la revista de Lezama operaba en el ámbito intelectual clásico, en la medida en que la pregunta por los orígenes era 
la pregunta por los orígenes de la cultura y lo cubano. Al disolver esa pregunta y hablar de una multiplicidad en fuga, Diáspora(s) despliega una idea que está orientada por la ruptura con los elementos fundacionales, desarrollando una conceptualización completamente secularizada de la política y los lenguajes. Tanto Orígenes como la revolución organizan la sociedad y la cultura planteando un Otro, en el sentido lacaniano de un tercero que organiza los lenguajes, es decir, lo que Dany-Robert Dufour denomina un gran Sujeto (31-131). En la revista de Lezama, ese rol lo ocupan aquellos que replicaran la posición de Cristo, por ejemplo José Martí. Martí organiza lo cubano, como si su sacrificio pusiera en marcha el lenguaje de la Isla. Del mismo modo, la revolución siempre necesitó un tercero, un gran Sujeto, ya sea que lo pensemos como el hombre nuevo, o que lo encarnemos en Castro, o bien, de una manera menos personal, en la revolución. Bajo ningún concepto podríamos considerar que esa forma de pensar la sociedad y la cultura es exclusivamente de Cuba. Es lo usual a lo largo de la modernidad. En este marco, Diáspora(s) pone de manifiesto que la estructura alrededor del Otro es una operación de lenguaje y, por lo tanto, una ficción que se mueve en el vacío.

Esto sitúa a Diáspora(s) en las reflexiones contemporáneas de la teoría literaria y el pensamiento político. Aunque la experiencia de la revista termina en 2002, su concepción de la lengua/poder articula con cuestiones como el fin de la autonomía, la mezcla de las artes y la superación de las formas de comunidad tradicionales. Pero creo importante establecer dos ejes de la revista que explican la capacidad que tiene para constituir un espacio que, aunque marginal, permite pensar lo contemporáneo.

En primer lugar, la crítica deconstructiva de Diáspora(s) nos ayuda a recordar la importancia que tiene la teoría para la historia política e intelectual. En particular, muestra que el umbral teórico tiene un impacto decisivo en todos los ámbitos del pensamiento. Recordemos que ese umbral se forma cuando los estudios literarios articulan con la lingüística estructuralista. Podríamos decir, de acuerdo con esto, que, más que la teoría literaria, la lingüística ha generado una revisión completa de los saberes, dando inicio a algo que podemos llamar el segundo momento de la Ilustración. Si el primer momento se propone criticar el sustento religioso de la sociedad y el poder y la determinación dogmática de los saberes, la lingüística, que en los años 40 y 50 interviene el psicoanálisis, la etnología y los estudios literarios, se propone deconstruir, con su concepción de que el lenguaje produce sentidos, subjetividades y organizaciones sociales, los elementos románticos que todavía se mantenían con vida en lo social: la nación, el ser humano, el mesianismo histórico, todo lo que se puso por encima de la historia. Con esto no estoy diciendo que Diáspora(s) lleve a cabo esta empresa; lo que estoy diciendo es que se trata de un punto de llegada de ella, y al mismo tiempo es un esclarecimiento definitivo, debido a que su propuesta teórica se desarrolla en el marco de una de las últimas sociedades que siguen organizándose de ese modo, por medio de un gran Sujeto.

En segundo lugar, si Diáspora(s) rompe con la organización moderna de la cultura, es claro que sueña con formas posmodernas. Bajo este concepto quisiera señalar algo bien preciso: la revista abandona la organización social en torno de un gran Sujeto y propone en su reemplazo la dispersión deleuzeana, es decir, esquizos en un rizoma (ese sería otro de los sentidos del título: las personas huyen en diáspora, de Cuba, pero también de cualquier lugar). En este sentido, la tensión entre la revista y el Estado muestra el choque de dos concepciones sociales, una moderna, pero que no puede sobrevivir sino es afianzándose en la posmodernidad, y una posmoderna, basada en lo posfundacional y en la defensa de una organización rizomática del poder. 
Pero, significativamente, la revista nunca caracterizó esa sociedad que imagina. Ya a mediados de los años 80 Severo Sarduy había mostrado su desencanto: la sociedad posmoderna es un encierro acaso más terrible que el de las sociedades disciplinarias. ${ }^{20} \mathrm{Y}$ también lo había mostrado Deleuze antes de suicidarse, cuando se puso hablar de las sociedades de control, por ejemplo en la entrevista que Diáspora(s) publica y de la cual no saca ninguna conclusión. Tal vez esto se deba a que se trata todavía en Cuba de un momento revolucionario. Pero no podemos dejar de notar que el rizoma es la estructura siempre mudable del neoliberalismo, la desterritorialización es la lógica del capital actual y el esquizo es el modelo de la nueva subjetividad, abierta al marketing y los lenguajes que lo cristalizan y disuelven en un presente perpetuo.

Publicada de una manera marginal, la revista sin embargo revela ese pasaje y pone de relieve, de una manera contundente, la forma en la que la teoría interviene, desde mediados del siglo XX, en lo social.

\section{Notas}

1 La lingüística estructuralista no afecta solamente a la teoría literaria, sino que también tiene un conocido impacto en el psicoanálisis y la etnología. Para verlo, podemos resumir la trayectoria de Roman Jakboson. Poco antes de la revolución, creó en Rusia, la OPOIAZ, cuna del formalismo ruso; en 1926, junto con el príncipe Trubetzkoy, el Círculo Lingüístico de Praga, en donde comenzaron a utilizar el concepto de linguiística estructural. Cuando se exilió en Estados Unidos, a principios de los años 40, se contactó con el medio psicoanalítico, en donde conoció a Reymond de Saussure, psicoanalista e hijo del lingüista. Este ya había pensado en abrir un canal entre la lingüística y el psicoanálisis, pero, de acuerdo con Elizabeth Roudinesco, fue Jakobson quien le mostró el verdadero alcance de la obra de su padre. En esa época también conoció a Claude Levi-Strauss, quien recuerda, en Decerca y de lejos, que, antes de vincularse con Jakobson, «Hacía estructuralismo sin saberlo» (61): «Jakobson me reveló la existencia de un cuerpo de doctrina ya constituido en una disciplina, la lingüística, que yo no había practicado nunca» (61-62). En los 50, Levi-Strauss le presentó a Lacan, a quien le mostró «Dos aspectos del lenguaje y dos tipos de afasia», aparecido en Fundamentals of Language (1956), en donde se interna en el campo psicoanalítico y sostiene que la metáfora y la metonimia son equiparables a las operaciones oníricas de condensación y desplazamiento que Sigmund Freud propuso en La interpretación de los sueños. Como se puede ver en la clase del 2 de mayo de 1956 de Las psicosis, el enfoque de Jakobson es la base para la idea de Lacan de que el inconsciente está es- tructurado como un lenguaje. Gracias a Jakobson, la lingüística estructuralista se convierte, así, en el umbral teórico de los estudios literarios, la antropología y el psicoanálisis.

2 Aunque se podrían tomar numerosos ejemplos, vale la pena resaltar la propuesta ética que Blanchot hace en El espacio literario en lo que respecta a la relación de la escritura con la Obra: «El punto central de la obra es la obra como origen, el que no se puede alcanzar, el único, sin embargo, que vale la pena alcanzar.// Este punto es la exigencia soberana, y si sólo podemos aproximarnos a ella realizando la obra, sólo aproximándonos, la realizamos» (48).

3 Como era obligado en Literal, el texto de Ludmer, como los otros que pertenecen al ámbito de la crítica, apareció sin firma.

4 Aunque en general los textos de Giordano trabajan esta ética del ensayo y lo inacabado, vale la pena recordar Razones de la crítica, que no en vano tiene el subtítulo de Sobre literatura, ética y política. Entre los ensayos que lo conforman, quisiera destacar «Literal y El frasquito: las contradicciones de la vanguardia», pues integra una serie de textos, como los que escribe sobre Masotta y Borges, que proponen una genealogía de sus ideas sobre teoría y crítica, y «La supersticiosa ética del lector. Notas para comenzar una polémica», en donde Giordano retoma de otro modo las propuestas de Ludmer sobre el texto y sus restos. El resto es, si podemos parafrasearlo así, una «potencia de inquietud» (15).

5 Entre tantos libros, se podrían destacar tres tesis doctorales centrales como las de Claudia Gilman, José Luis de Diego y Andrea Giunta: Entre la pluma y el fusil, ¿Quién de nosotros 
escribirá el Facundo? y Vanguardia, internacionalismo y política, que se defendieron y publicaron alrededor del año 2000.

6 La revisión más importante está ligada a una caracterización de los campos de producción cultural en los países periféricos. Sarlo y Altamirano destacan, en este sentido, la necesidad de relativizar aún más la autonomía y tomar en cuenta las relaciones de escritores e intelectuales con los países centrales: «Las metrópolis culturales operan no sólo como horizonte de paradigmas estéticos e intelectuales, sino como instancias definitivas de consagración» (86).

7 De Diego demuestra que el paso hacia la democracia se debe a una serie de causas centrales. Entre ellas, menciona la derrota de las vías revolucionarias por parte de la última dictadura militar y la experiencia dramática del exilio; en el plano internacional, añade el descrédito del «socialismo real», en China tras la muerte de Mao y en Vietnam con la sangrienta invasión a Camboya de 1978, el desprestigio igual de creciente de los movimientos separatistas como ETA y las Brigadas Rojas en Italia, la consecuente retracción del apoyo a los movimientos revolucionarios todavía en pie, como la guerrilla sandinista y, por supuesto, la consolidación de los partidos socialdemócratas en Europa. Podemos agregar, a estas causas, el agotamiento de la población respecto de las exigencias de una cultura extremadamente politizada y a la vez diezmada, algo que expresó Charly García en la canción «Yo no quiero volverme tan loco», en la que rechaza «vestirse de rojo» y quiere ver «más delirantes por ahí/bailando en una calle cualquiera».

8 Como se sabe, Piñera pasó varias temporadas en Argentina. Habría que agregar la cercanía que siempre se ha visto entre Orígenes y Sur. Sobre este tema, es indispensable la consulta del libro de Nancy Calomarde El diálogo oblicuo. Orígenes y Sur: fragmentos de una escena de lectura latinoamericana (1944-1956).

9 La edición facsimilar está antecedida por un nutrido número de textos de presentación, recuerdos y entrevistas, en los que se encuentran los datos principales de la publicación. A los fines específicos del grupo, hay que destacar los trabajos de Cabello e Idalia Morejón. Ambos manifiestan que los escritores de Diáspora(s) formaron un grupo. En el texto con el que participa, Antonio José Ponte discute esta caracterización: no se trató de un grupo orgánico, y la revista adoleció, según su punto de vista, de una cierta falta de organicidad. La revista ha recibido varias recensiones críticas, entre las que resulta fundamental, para este trabajo, el trabajo de Guadalupe Silva «La isla erosionada. El proyecto Diáspora(s) - Cuba, 1997-2002».
10 Tomo la caracterización de estos tres autores de los textos que publicaron en la edición facsimilar de Diáspora(s). De acuerdo con esto, la revista propone una escritura que circula afuera del espacio público. Otros testimonios que se encuentran en la edición facsimilar son esclarecedores en este sentido. Reina María Rodríguez afirma que se trataba de «una revista semi-clandestina, porque no pertenecía a institución alguna. Nombrarse como grupo era un hecho imposible por entonces y hacer una revista que no fuera institucional mucho más» (55). Daniel Balderston cuenta un episodio simbólico de esta situación. En 2001, llevó a profesores y estudiantes de la Universidad de Iowa y de Grinnell College a La Habana y desarrollaron unas sesiones de intercambio con intelectuales y artistas cubanos, la mayoría de las cuales se realizaron en un edificio de la UNEAC. «Cuando llegó la sesión sobre revistas insistí en que Aguilera y Marqués de Armas participaran, a pesar de que su revista no gozaba de ningún tipo de aprobación oficial. Las autoridades locales de la UNEAC (López Sacha en literatura y Carlos Martí en la presidencia) se opusieron pero lo logré (nosotros les estábamos pagando por «organizar» esos encuentros, y pude insistir en que las inclusiones las decidía yo)» (91).

11 Sobre este tema hay importantes monografías. Quisiera resaltar, por su claridad, Historia de la gubernamentalidad. Razón de Estado, liberalismo y neoliberalismo en Michel Foucault, de Santiago Castro-Gómez.

12 Los números de página se toman de la edición facsimilar. Cuando sea necesario para el desarrollo argumental, aclaro el número de la revista y el año de publicación originales en el que aparece un texto determinado.

13 Esta interpretación siempre se mantuvo en tensión con la intelectualidad en el exilio. Desde afuera se recordó que Lezama terminó sus últimos años en el ostracismo y su hermana Eloísa publicó su correspondencia, en donde Lezama se quejaba amargamente del exilio de la familia y los amigos, las carencias económicas y el encierro al que lo había sometido la revolución desde el caso Padilla (1971).

14 La frase es la siguiente: «Mostramos la mayor cantidad de luz que puede, hoy por hoy, mostrar un pueblo en la tierra» (1975:840). Se trata del colofón, «Se invoca al ángel de la Jiribilla», famosísimo como texto suelto y como concepto. Si hacemos caso a la edición de Ciro Bianchi Ross de Imagen y posibilidad, Lezama ya lo había presentado en «Lectura».

15 Ambos textos fueron presentados en la mesa redonda «Orígenes y su influencia en los nuevos escritores», que se realizó en 
el Coloquio sobre Orígenes, de 1994, en el que se conmemoraban los 50 años de la creación de la revista de Lezama. Víctor Fowler Calzada presenta un breve recuerdo del evento y las reacciones del público en el testimonio que integra la edición facsimilar de Diáspora(s) (2013:60).

16 Para la concepción mesiánica del tiempo en Cuba, hay que destacar el libro de Rafael Rojas Tumbas sin sosiego. Al mismo tiempo, para la importancia que esa concepción tenía para la mayoría de la población, es importante recordar la frase con la que sintetiza esa cuestión Tulio Halperín Donghi en Historia contemporánea de América Latina: «La revolución que triunfa en el Año Nuevo de 1959, que no es por entonces una revolución social, es en cambio la siempre renaciente revolución cubana, que sigue aspirando a una rehabilitación a la vez moral y nacional, y está esta vez resuelta a no dejarse extraviar en el camino» (529).

17 Esa factura católica para pensar la revolución es explícita en Lezama. En «El 26 de Julio: imagen y posibilidad» sostiene: «Llevamos un tesoro en un vaso de barro, dicen los Evangelios, y ese tesoro es captado por la imagen, su fuerza operante es la posibilidad. Pero la imagen tiene que estar al lado de la muerte, sufriendo la abertura del arco en su mayor enigma y fascinación, es decir, en la plenitud de la encarnación, para que la posibili- dad adquiera un sentido y se precipite en lo temporal histórico» (1981:19). Lezama se refiere al 26 de julio, es decir, al sacrificio que se realiza en el asalto al cuartel Moncada. El sacrificio, verdadero el eje de la poesía de Lezama, opera también en la reconstrucción de la muerte del dirigente estudiantil Rafael Trejo y por supuesto en ese otro gran sacrificio que es la muerte de Martí.

18 Con leves modificaciones, la frase aparece en la clase «Del barroco», del seminario Aun, que Lacan dicta el 8 de mayo de 1973: «El barroco es la regulación del alma por la escopia corporal» (140). La reposición de Marqués de Armas es precisa y aguda. Por una parte, remite al barroco lezamiano y a su vuelco revolucionario; por la otra, sugiere que los individuos se sacrifican ante la mirada gozosa de ese Otro que organiza la escena, ya sea que se trate de la revolución, el hombre nuevo o Fidel Castro.

19 Diáspora(s) publicó un diálogo radial entre Adorno y Canetti en el que se refieren abundantemente a la masa en el número 4/5: «Elías Canetti: discusión con Theodor W. Adorno» (2013:421-431).

20 Este aspecto se puede advertir en las últimas publicaciones de Sarduy. Sobre el desencanto de Sarduy, Deleuze y Perlongher, ver el último capítulo de Del Concilio de Trento al sida. Una historia del Barroco.

\section{Referencias bibliográficas}

Para José Lezama Lima. (1985). Casa de las Américas, XXVI(152):3-4.

Altamirano, C. y Sarlo, B. (1993). Literatura/sociedad. Buenos Aires: Edicial.

Antelo, R. (2015). Archifilologías latinoamericanas. Lecturas tras el agotamiento. Córdoba: Eduvim.

Barthes, R. (1997). El placer del texto y Lección inaugural. México: Siglo XXI.

Blanchot, M. (1992). El espacio literario. Barcelona, España: Paidós.

Bourdieu, P. (2003). Campo intelectual, campo de poder. Buenos Aires: Quadrata.

Cabezas Miranda, J. (2013). Revista Diáspora(s). Edición facsimilar(1997-2002). Barcelona: Red Ediciones.

Calomarde, N. (2010). El diálogo oblicuo. Orígenes y Sur: fragmentos de una escena de lectura latinoamericana (1944-1956). Córdoba: Alción.

Castro-Gómez, S. (2010). Historia de la gubernamentalidad. Razón de Estado, liberalismo y neoliberalismo en Michel Foucault. Bogotá: Siglo del Hombre Editores.

Dalmaroni, M. (1997). La moda y «la trampa del sentido común». Sobre la operación Raymond Williams en Punto de vista. Orbis Tertius, II(5), 1-7.

De Diego, J. L. (2001). ¿Quién de nosotros escribirá el Facundo? La Plata: Al Margen.

De Man, P. (1990). La resistencia a la teoría. Madrid: Visor.

Deleuze, G. y Guattari, F. (1997). Mil mesetas. Barcelona: Pretextos.

Derrida, J. (1998). Espectros de Marx El estado de la deuda, el trabajo del duelo y la nueva internacional. Madrid: Trotta. 
Dufour, D. R. (2009). El arte de reducir cabezas. Sobre la servidumbre del hombre liberado en la era del capitalismo total. Buenos Aires: Paidós.

Foucault, M. (1992). El orden del discurso. Buenos Aires: Tusquets.

(1998). La voluntad de saber. Madrid: Siglo XXI.

(2000). Vigilary castigar. México: Siglo XXI.

(2001). Defender la sociedad. Buenos Aires: Fondo de Cultura Económica.

(2004). Nacimiento de la biopolítica. Buenos Aires: Fondo de Cultura Económica.

- (2006). Seguridad, territorio, población. Buenos Aires: Fondo de Cultura Económica.

(2008). Tecnologías del yo. Buenos Aires: Paidós.

García, G. y Lamborghini, O. (1973). El matrimonio entre la utopía y el poder. Literal, (1): 35-46.

Gilman, C. (2003). Entre la pluma y el fusil. Buenos Aires: Siglo XXI.

Giordano, A. (1999). Razones de la crítica.Sobre literatura, ética y política. Buenos Aires: Colihue. (2005). Modos del ensayo. De Borges a Piglia. Rosario: Beatriz Viterbo.

Giunta, A. (2001). Vanguardia, internacionalismo y política. Arte argentino en los años sesenta. Buenos Aires: Paidós.

Halperín Donghi, T. (1997). Historia contemporánea de América Latina. Madrid: Alianza.

Iriarte, I. (2017). Del Concilio de Trento al sida. Una historia del Barroco. Buenos Aires: Prometeo.

Jakoboson, R. (1973). Dos aspectos del lenguaje y dos tipos de afasia. En R. Jakobson y M. Halle. Fundamentos del lenguaje. Madrid: Ayuso, 99-143.

Lacan, J. (2000). La ética del psicoanálisis. Buenos Aires: Paidós

- (2001). Aun. Buenos Aires: Paidós.

(2013). Las psicosis. Buenos Aires: Paidós.

Laclau, E. y Chantal, M. (1987). Hegemonía y estrategia socialista. Madrid: Siglo XXI.

Levis-Strauss, C. y Eribon, D. (1990). De cerca y de lejos. Madrid: Alianza.

Lezama Lima, J. (1975). Obras Completas I. Madrid: Aguilar.

(1981). Imagen y posibilidad (edición de Ciro Bianchi Ross). La Habana: Letras Cubanas.

Ludmer, J. (1973). El resto del texto. Literal, (1), 47-52.

Rama, A. (1998). La ciudad letrada. Montevideo: Arca.

Rancière, J. (2011). Política de la literatura. Buenos Aires: El Zorzal.

(2014). El hilo perdido. Ensayos sobre la ficción moderna. Buenos Aires: Manantial.

Rojas, R. (2006). Tumbas sin sosiego. Barcelona: Anagrama.

Roudinesco, E. (2005). Lacan. Buenos Aires: Fondo de Cultura Económica.

Sarlo, B. (2014). El campo intelectual: un espacio doblemente fracturado. En S. Sosnowski, editor. Represión y reconstrucción de una cultura: el caso Argentino. Buenos Aires: Eudeba, 96-108.

Silva, G. (2015). La isla erosionada. El proyecto Diáspora(s) - Cuba, 1997-2002. El jardín de los poetas, I(1): 145-163. 